\title{
DIET OF THE GREAT HORNED OWL IN CENTRAL SASKATCHEWAN
}

DYLAN D. VON KUSTER, 303 Avenue F North, Saskatoon, Saskatchewan. S7L 1 V9 and DAVID SCHNEBERGER, 111 7th Street East, Saskatoon, Saskatchewan. S7H OW7

Introduction In our Grade 12 year at Aden Bowman Collegiate, we needed a project for our science fair. Dr. Stuart Houston suggested analysing Great Horned Owl pellets that he and his climbers had collected over four years from various areas in central Saskatchewan, from Prince Albert south almost to Regina. This paper reports the results of that study.

We had four objectives: To discover (1) the overall diet of this bird;
(2) variations in prey captured for the years 1986, 1987 and 1989; (3) differences in diet between vegetation zones; and (4) the average size of an owl pellet. Because there are such great differences in the mass (size) of prey such as Deer Mice and Snowshoe Hares, we then recalculated our initial data to determine the relative importance of each prey animal in the diet.

The pellets had been bagged and labelled as to place and date found.

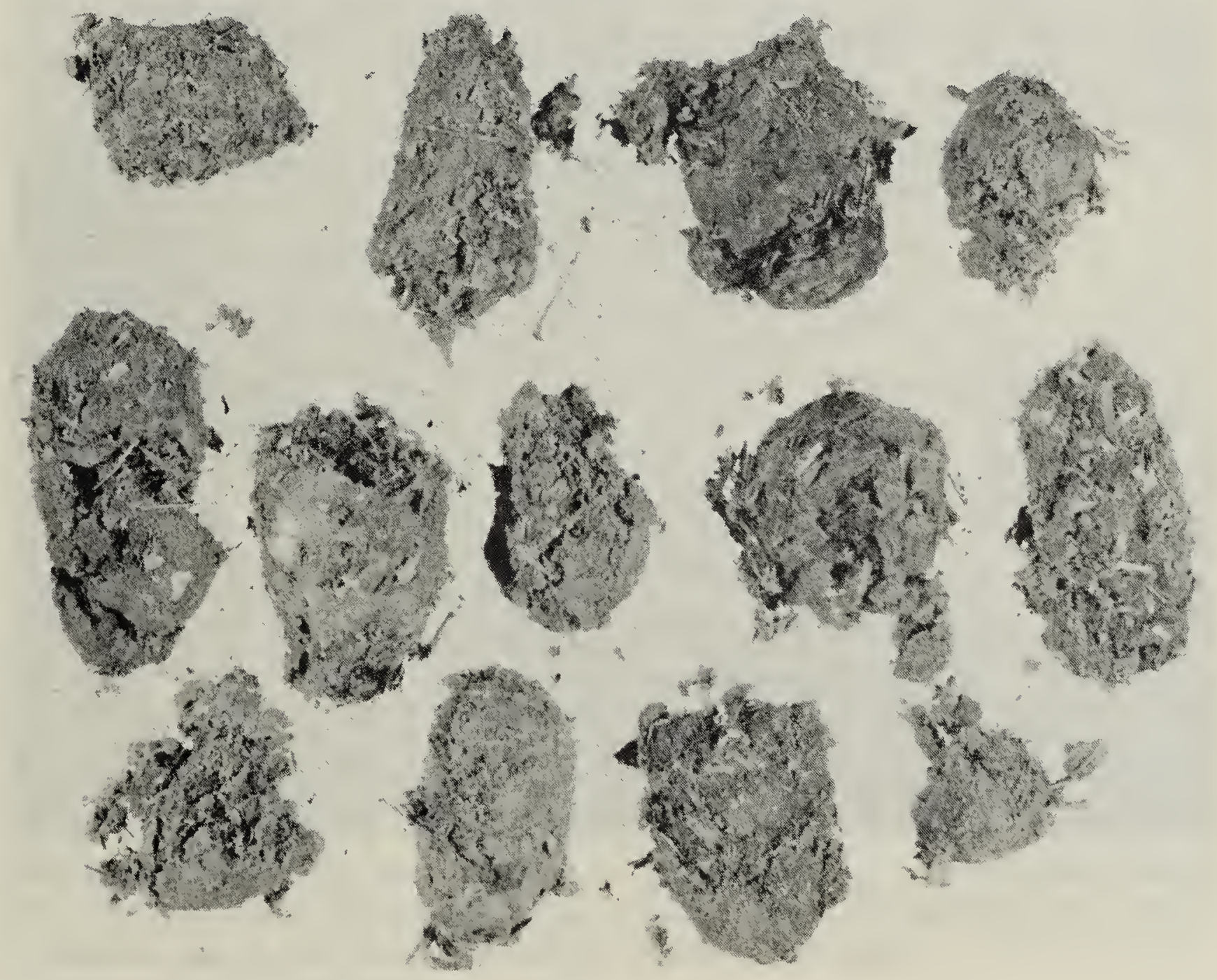

Great Horned Owl pellets.

C. Stuart Houston 


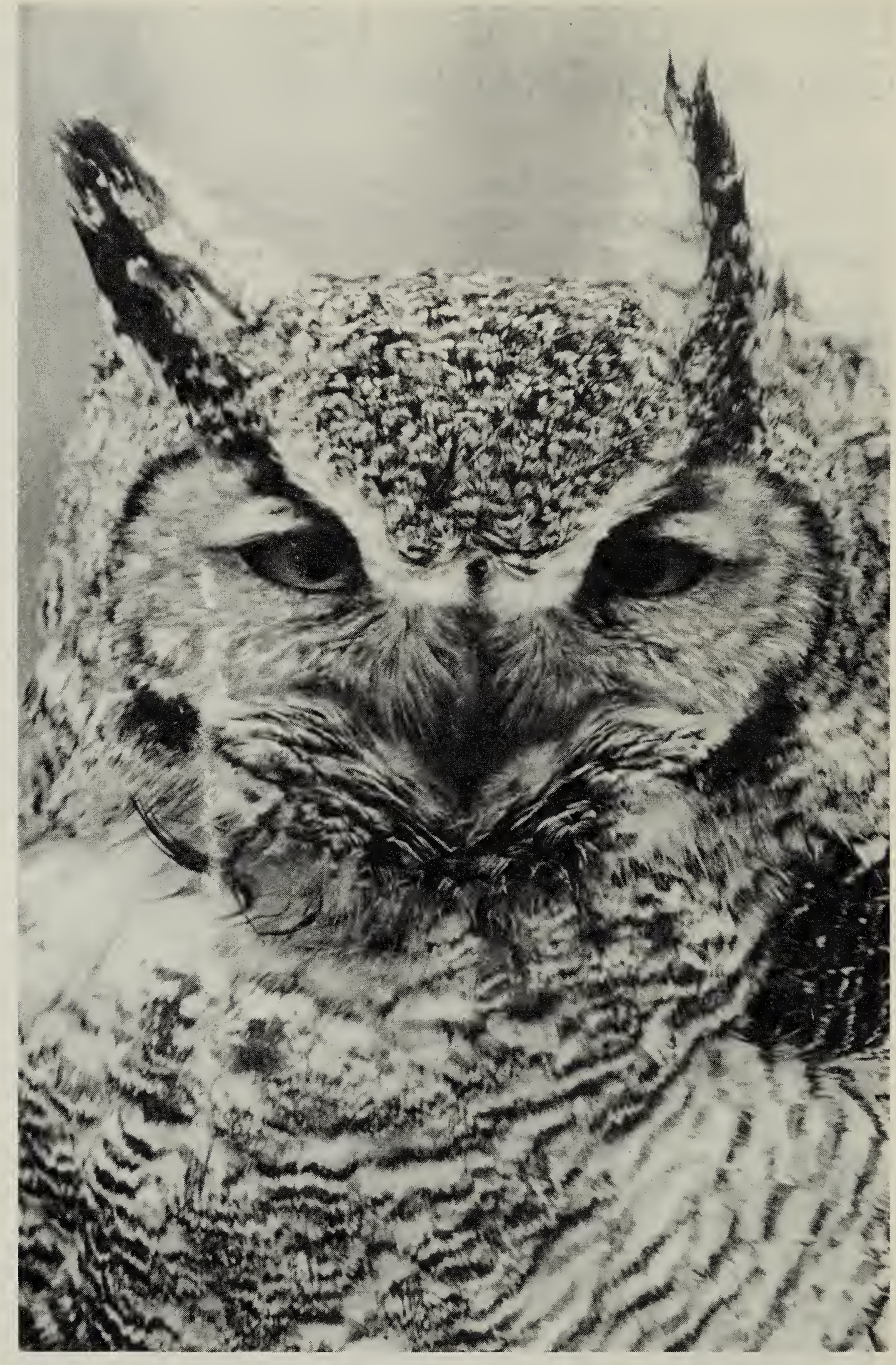

Great Horned OWI

Gary Seib 
Table 1: DIET OF THE GREAT HORNED OWL IN SASKATCHEWAN BY YEAR AND NUMBER OF PREY ITEMS

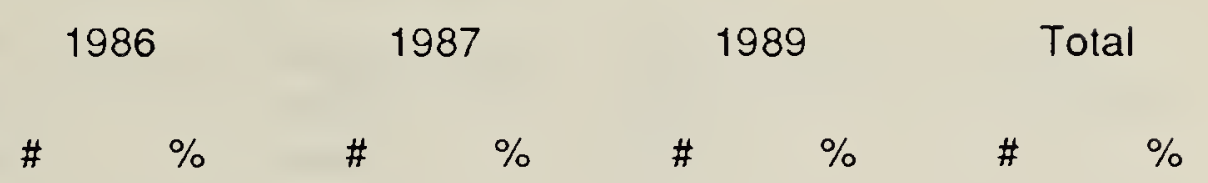

MAMMALS

$\begin{array}{lrrrrrrrr}\text { Deer Mouse } & 126 & 44.5 & 344 & 60.0 & 315 & 66.5 & 785 & 59.0 \\ \text { Northern Pocket Gopher } & 50 & 17.7 & 93 & 16.2 & 40 & 8.4 & 183 & 13.8 \\ \text { Meadow Vole } & 48 & 17.0 & 54 & 9.4 & 64 & 13.5 & 166 & 12.5 \\ \text { Snowshoe Hare } & 14 & 5.0 & 39 & 6.8 & 20 & 4.2 & 73 & 5.5 \\ \text { Red-backed Vole } & 3 & 1.1 & 4 & 0.7 & 6 & 1.3 & 13 & 1.0 \\ \text { Richardson's Ground Squirrel } & 0 & 0.0 & 3 & 0.5 & 2 & 0.4 & 5 & 0.4 \\ \text { Least Weasel } & 0 & 0.0 & 0 & 0.0 & 3 & 0.6 & 3 & 0.2 \\ \text { Muskrat } & 0 & 0.0 & 1 & 0.2 & 1 & 0.2 & 2 & 0.2 \\ \text { Total Mammals } & 241 & 85.3 & 538 & 93.8 & 451 & 95.1 & 1,230 & 92.6\end{array}$

BIRDS

House Sparrow

Blue-winged Teal

3.2

0.9

1.7

22

1.7

Mallard

2.8

1.2

1.3

21

1.6

Ruffed Grouse

0.7

$0.2 \quad 12$

0.9

Red-necked Grebe

0.5

$0.4 \quad 11$

0.8

Gadwall

0.7

0.6

0.8

Black-billed Magpie

1.1

0.2

0.6

0.4

0.2

0.4

American Robin

0.5

0.0

0.3

American Crow

0.4

0.0

0.0

0.2

American Coot

0.0

0.0

0.1

Gray Partridge

0.4

0.0

0.2

0.1

Western Meadowlark

0.2

0.0

0.1

Total Birds

$0 \quad 0.0$

6.2

4.8

7.6

Grand Total

$283 \quad 100$

$573 \quad 100.0$

474

$99.9 \quad 1,330$

100.2

We borrowed skeletons of the prey species from W. Bruce McGillivray of the Provincial Museum of Alberta, Edmonton, and later, with the assistance of Dr. Nigel Mathews, photographed them because they had to be returned prior to completion of our study. Then we measured and dissected the pellets, bagging the bones and some of the fur and feathers for later identification from skeletons and photos.
Results Overaii, Deer Mice made up $59 \%$ of the 1,330 prey items (Table 1). Northern Pocket Gophers comprised $14 \%$, Meadow Voles $12 \%$ and Snowshoe Hares nearly 6\%, these four mammal species comprising $90 \%$ of the prey items. Birds, ranging in size from House Sparrow to Mallard, formed only $8 \%$ of the prey items.

On an annual basis, the major 
Table 2: DIET OF THE GREAT HORNED OWL IN SASKATCHEWAN

BY DIFFERENT VEGETATION AREAS

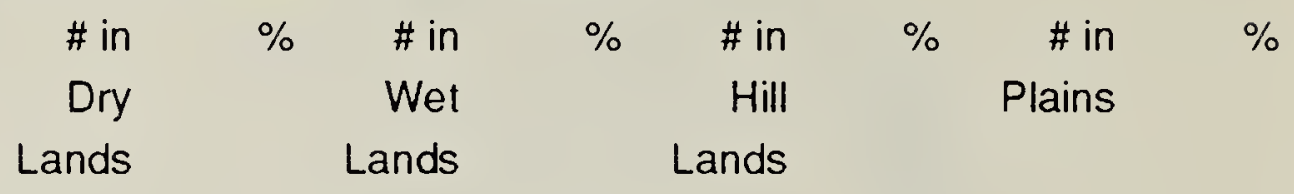

MAMMALS

$\begin{array}{lrrrrrrrr}\text { Deer Mouse } & 43 & 39.8 & 1 & 25.0 & 131 & 52.2 & 610 & 63.1 \\ \text { Northern Pocket Gopher } & 19 & 17.6 & 1 & 25.0 & 49 & 19.5 & 114 & 11.8 \\ \text { Meadow Vole } & 17 & 15.7 & 1 & 25.0 & 26 & 10.4 & 122 & 12.6 \\ \text { Snowshoe Hare } & 14 & 13.0 & 1 & 25.0 & 23 & 9.2 & 36 & 3.7 \\ \text { Red-backed Vole } & 2 & 1.9 & 0 & 0.0 & 2 & 0.8 & 9 & 0.9 \\ \text { Richardson's Ground Squirrel } & 0 & 0.0 & 0 & 0.0 & 3 & 1.2 & 2 & 0.2 \\ \text { Least Weasel } & 0 & 0.0 & 0 & 0.0 & 1 & 0.4 & 2 & 0.2 \\ \text { Muskrat } & 1 & 0.9 & 0 & 0.0 & 0 & 0.0 & 1 & 0.1 \\ \text { Total Mammals } & 96 & 88.9 & 3 & 75.0 & 235 & 93.7 & 896 & 92.6\end{array}$

BIRDS

House Sparrow

Blue-winged Teal

Mallard

Ruffed Grouse

Red-necked Grebe

Gadwall

Black-billed Magpie

American Robin

American Crow

American Coot

Gray Partridge

Western Meadowlark

Total Birds

Grand Total
108

$\begin{array}{rr}1 & 0.9 \\ 1 & 0.9 \\ 3 & 2.8 \\ 1 & 0.9 \\ 2 & 1.9 \\ 1 & 0.9 \\ 0 & 0.0 \\ 1 & 0.9 \\ 0 & 0.0 \\ 1 & 0.9 \\ 0 & 0.0 \\ 1 & 0.9 \\ 12 & 11.0\end{array}$

99.9

$\begin{array}{rr}0 & 0.0 \\ 0 & 0.0 \\ 1 & 25.0 \\ 0 & 0.0 \\ 0 & 0.0 \\ 0 & 0.0 \\ 0 & 0.0 \\ 0 & 0.0 \\ 0 & 0.0 \\ 0 & 0.0 \\ 0 & 0.0 \\ 1 & 25.0 \\ 1 & 25.0\end{array}$

$4 \quad 100.0$
0.0

0.0

25.0

0.0

0.0

0.0

0.0

0.0

0.0

0.0

0.0

25.0

25.0

$\begin{array}{rrrr}3 & 1.2 & 18 & 1.9 \\ 5 & 2.0 & 15 & 1.6 \\ 0 & 0.0 & 8 & 0.8 \\ 1 & 0.4 & 9 & 0.9 \\ 3 & 1.2 & 6 & 0.6 \\ 0 & 0.0 & 7 & 0.7 \\ 1 & 0.4 & 4 & 0.4 \\ 1 & 0.4 & 2 & 0.2 \\ 1 & 0.4 & 2 & 0.2 \\ 0 & 0.0 & 0 & 0.0 \\ 1 & 0.4 & 0 & 0.0 \\ 0 & 0.0 & 0 & 0.0 \\ 16 & 6.4 & 71 & 7.3\end{array}$

$\begin{array}{llll}251 & 100.1 & 967 & 99.9\end{array}$

mammals held the same positions except for pocket gopher and vole in 1989 (Table 1). Birds varied from 5\% in 1987 to $15 \%$ in 1986. However, one would expect these results to vary at different points during the ten-year population cycle of the Snowshoe Hare, which was scheduled to (but failed to) peak in 1990.

The top three mammals (Meadow
Vole, Northern Pocket Gopher, and Snowshoe Hare), continued to be the top three prey items in all vegetation areas (Table 2). However, Snowshoe Hares were absent in the southern drylands. Birds made up almost twice as many prey items in the drylands $(11 \%)$ as in the hills or rangelands $(6 \%)$ and agricultural plains $(7 \%)$.

The foregoing calculations were 
Table 3: DIET OF THE GREAT HORNED OWL IN SASKATCHEWAN

BY MASS OF PREY

\begin{tabular}{|c|c|c|c|c|}
\hline & Number & $\begin{array}{l}\text { Average Weight } \\
\text { (grams) }\end{array}$ & $\begin{array}{l}\text { Total Weight } \\
\text { Species }\end{array}$ & $\begin{array}{l}\% \text { Diet } \\
\text { by Weight }\end{array}$ \\
\hline \multicolumn{5}{|l|}{ MAMMALS } \\
\hline Deer Mouse & 785 & 25.0 & 19,625 & 8.9 \\
\hline Northern Pocket Gopher & 183 & 100.0 & 18,300 & 8.3 \\
\hline Meadow Vole & 166 & 78.5 & 13,031 & 5.9 \\
\hline Snowshoe Hare & 73 & $1,500.0$ & 10,9500 & 49.5 \\
\hline Red-backed Vole & 13 & 30.0 & 390 & 0.2 \\
\hline Richardson's Ground Squirrel & 5 & 450.0 & 2,250 & 1.0 \\
\hline Least Weasel & 3 & 70.0 & 210 & 0.1 \\
\hline Muskrat & 2 & $1,200.0$ & 2400 & 1.1 \\
\hline Total Mammals & 1,230 & $3,453.5$ & 165,706 & 75.0 \\
\hline \multicolumn{5}{|l|}{ BIRDS } \\
\hline House Sparrow & 22 & 26.7 & 587 & 0.3 \\
\hline Blue-winged Teal & 21 & 375.6 & 7,888 & 3.6 \\
\hline Mallard & 12 & $13,32.4$ & 15,989 & 7.2 \\
\hline Ruffed Grouse & 11 & 626.6 & 6,783 & 3.1 \\
\hline Red-necked Grebe & 11 & $1,304.1$ & 14,345 & 6.5 \\
\hline Gadwall & 8 & 793.8 & 6,350 & 2.9 \\
\hline Black-billed Magpie & 5 & 170.1 & 851 & 0.4 \\
\hline American Robin & 4 & 85.0 & 340 & 0.2 \\
\hline American Crow & 3 & 503.2 & 1,510 & 0.7 \\
\hline American Coot & 1 & 538.6 & 539 & 0.2 \\
\hline Gray Partridge & 1 & 382.7 & 283 & 0.1 \\
\hline Western Meadowlark & 1 & 104.6 & 105 & 0.1 \\
\hline Total Birds & 100 & $62,33.4$ & 55,570 & 25.3 \\
\hline Grand Total & 1,330 & $9,686.9$ & 221,276 & 100.3 \\
\hline
\end{tabular}

based on numbers of prey items identified as eaten by the owls. However, because of differences in size, they do not reflect each species' contribution to the Great Horned Owl's diet. Applying the average weight of live animals to the numbers caught, it turned out that Snowshoe Hares make up nearly $50 \%$ of the owl's diet in terms of biomass (Table 3). Deer Mice and Pocket Gophers drop to $9 \%$ and $8 \%$, respectively, and the Meadow Vole to $6 \%$. Birds went from

$8 \%$ of the prey items to $25 \%$ of the biomass - and excepting hares, a larger proportion than all other mammals combined.

Whole pellets varied considerably in length - from 2.0 to $12.5 \mathrm{~cm}$ (Table 4). The average length as well as the most frequent length was 6.0 $\mathrm{cm}$. A pellet which contained only Deer Mice averaged between 2.6 and 3.0 mice per pellet. 


\section{Table 4: AVERAGE SIZE OF PELLETS \\ OF THE GREAT HORNED OWL IN SASKATCHEWAN}

\begin{tabular}{|c|c|c|c|c|c|}
\hline $\begin{array}{l}\text { Size } \\
(\mathrm{cm})\end{array}$ & Number & $\begin{array}{l}\text { Size } \\
(\mathrm{cm})\end{array}$ & Number & $\begin{array}{l}\text { Size } \\
(\mathrm{cm})\end{array}$ & Numbe \\
\hline 2.0 & 2 & 5.5 & 31 & 7.7 & 1 \\
\hline 2.2 & 1 & 5.6 & 2 & 7.8 & 2 \\
\hline 2.5 & 1 & 5.7 & 6 & 7.9 & 1 \\
\hline 2.6 & 1 & 5.8 & 6 & 8.0 & 18 \\
\hline 3.0 & 12 & 5.9 & 4 & 8.2 & 3 \\
\hline 3.5 & 7 & 6.0 & 62 & 8.5 & 6 \\
\hline 3.6 & 2 & 6.1 & 4 & 8.6 & 2 \\
\hline 3.9 & 1 & 6.2 & 6 & 8.9 & 2 \\
\hline 4.0 & 27 & 6.3 & 2 & 9.0 & 8 \\
\hline 4.2 & 3 & 6.4 & 7 & 9.2 & 2 \\
\hline 4.3 & 1 & 6.5 & 42 & 9.4 & 1 \\
\hline 4.4 & 1 & 6.6 & 4 & 9.5 & 2 \\
\hline 4.5 & 27 & 6.7 & 3 & 9.6 & 1 \\
\hline 4.6 & 2 & 6.8 & 2 & 9.7 & 1 \\
\hline 4.7 & 3 & 6.9 & 3 & 9.9 & 1 \\
\hline 4.8 & 1 & 7.0 & 36 & 10.0 & 2 \\
\hline 4.9 & 3 & 7.1 & 5 & 10.5 & 1 \\
\hline 5.0 & 43 & 7.2 & 6 & 10.8 & 1 \\
\hline 5.2 & 6 & 7.3 & 2 & 11.0 & 1 \\
\hline 5.3 & 1 & 7.5 & 18 & 12.0 & 1 \\
\hline 5.4 & 3 & 7.6 & 4 & 12.5 & 1 \\
\hline
\end{tabular}

Our display at the Saskatoon Regional Science Fair, and later at the Canadian National Science Fair in Windsor, Ontario, included a map of the landscapes of central Saskatchewan, photographs of owl pellets, and skeletons of prey animals. ${ }^{1}$ The project won first in the Senior Life Science category and Best of Show at Aden Bowman Collegiate, first in Senior Life Science and Students' Choice at the Regional Science Fair, and a Bronze Medal at the National Science Fair.

1. ACTON, D.F. 1977. Landscapes of Southern Saskatchewan. (map) Department of Mines, Energy and Resources, Ottawa.
2. AUSTING, G.R., and J.B. HOLT, JR 1966. The world of the Great Horned Owl. J.B. Lippincott, New York.

3. BANFIELD, A.W.F. 1974. The mammals of Canada. University of Toronto Press, Toronto.

4. GODFREY, W.E. 1986. The birds of Canada, revised edition. National Museum of Canada, Ottawa.

5. KEITH, L.B. 1977. Great Horned Owl. Hinterland Who's Who. Canadian Wildlife Service, Ottawa, 4 pp.

6. MIDDLETON. 1985. All the world's animals: birds, owls, parrots and waders. Torstar Books, Toronto.

7. PERRINS, C.M. and MACDONALD, D. 1985. All the world's animals: rodents. Torstar Books, Toronto. 